Recebido: 28/11/2016

Aprovado:06/12/2016

\title{
A religiosidade sustentada pelo medo: elementos de mudança no imaginário medieval a partir da peste do século XIV.
}

Thiago Fernando Dias ${ }^{*}$

\begin{abstract}
Resumo: A maior onda de Peste Negra da Europa, o fluxo de 1348, ocasionou mudanças no Imaginário de uma parcela considerável da população, proporcionando, a partir da realidade por ela imposta, alterações nas práticas religiosas vigentes. Os impactos demográficos e sociais causados pelas inúmeras mortes desafiaram as instituições do momento; os líderes citadinos com sua legislação, os reis com seus editais e o clero com suas orações não foram suficientes para conter o fluxo pestilento. O grau de contágio e a propagação da peste foi tão intenso que qualquer pessoa com sintomas manifestos tornava-se uma ameaça à vida. Neste artigo, buscaremos entender de que maneira o medo da morte interferiu e mudou as práticas religiosas (religiosidade) da população no momento estudado. Procuraremos, ainda, analisar como a Igreja explicou a eclosão da Peste e justificou o clima de insegurança, consternação e desespero ocasionado pelo período pestilento. Para tal análise, situamonos na região da Península Itálica durante a Baixa Idade Média, mais especificamente no período de transição da primeira para a segunda metade do século XIV. Embora essa delimitação seja predominante, não nos deteremos apenas a esse espaço temporal e geográfico, pois avanços e recuos serão recorrentes no texto a partir de exemplos pontuais.
\end{abstract}

Palavras-chave: Peste Negra; Imaginário; Religiosidade.

Abstract: The largest Black Death wave in Europe, in 1348, caused changes in the Imaginary of a considerable portion of the population at that time, providing, from the reality imposed by it, changes in current religious practices. The demographic and social impacts caused by countless deaths defied the institutions of that time; city leaders with their legislation, kings with their edicts, and the clergy with their prayers were not enough to contain the pestilent flow. The degree of contagion and the spread of the plague was so intense that anyone with manifest symptoms became a threat to life. In this article, we will try to understand how the fear of death interfered and changed the religious practices of the population (religiosity) at the time studied. We will also try to analyze how the Church explained the outbreak of the Plague, justified the climate of insecurity, consternation and despair caused by the pestilent period. For this analysis, we chose to look at the region of the Italic Peninsula during the Low Middle Ages, more specifically, in the transition period from the first to the second half of the fourteenth century. Although this delimitation is predominant, we will not only dwell on this temporal and geographical space, but we will also make recurrent advances and retreats in the text from specific examples.

Keywords: Black Death; Imaginary; Religiosity.

\footnotetext{
* Mestrando do Programa de Pós-Graduação em História e Sociedade da Universidade Estadual Paulista (Unesp), Faculdade de Ciências e Letras, Assis; Bolsista CNPQ; membro do NEAM-Núcleo de Estudos Antigos e Medievais da UNESP.
} 
Ao longo da história, as incertezas com as epidemias, catástrofes ou fenômenos inexplicáveis intervieram e influenciaram, cada uma a seu modo, nas questões do cotidiano da sociedade no momento de sua propagação. Ainda que no decurso dos séculos diversos surtos não fossem pormenorizados e costumassem ser genericamente rotulados de peste, inclusive pela Igreja, muitos deles não foram causados pelo bacilo agente da Peste Negra (Yersinia pestis), mas foram, provavelmente, epidemias de varíola, tifo exantemático (erupção cutânea), cólera, malária ou febre tifoide (Cf. REZENDE, 2009: 73).

Os equívocos na nomenclatura ${ }^{1}$ e do quadro clínico concernente à Peste Negra $^{2}$ foram corrigidos apenas a partir do século XX, quando a bactéria causadora do flagelo foi descoberta pelo franco-suíço Alexander Yersin (1863-1943). O bacteriologista a identificou dentro do sistema digestivo da pulga. Por essa razão, foi batizada como Yersínia Pestis.

Aparentemente, o relato mais antigo acerca da manifestação do bacilo Yersínia Pestis e suas consequências é a descrição feita por Sushruta $^{3}$, no século VI a.C. (Cf. CASTIGLIONI, 1947: 104). Nos escritos milenares da medicina hindu, as principais características da peste já

\footnotetext{
${ }^{1}$ A origem da expressão permanece até hoje um mistério, pois nem mesmo os contemporâneos utilizavam-na para descrever a onda pestilenta no período. A frase de origem latina, atra mors, já era empregada por Seneca, no século I a.C. em relação a uma praga, contudo, não com as mesmas características da Peste Negra. Sua designação para a doença endêmica do século XIV foi feita apenas no século XVII por Johannes Isaacus Pontanus, em 1631. ARRIZABALAGA, 1991: 79.

${ }^{2} \mathrm{O}$ desenvolvimento do quadro clínico provocado pelo contágio do bacilo promovedor da peste deve-se à inoculação da bactéria pelo organismo do ser humano; contudo, são várias as maneiras desse processo ocorrer: pelo ar, pelo contato com o sangue da pessoa infectada, através da picada da pulga ou mesmo pela mordida do rato contaminado. No organismo humano, a peste apresenta-se, essencialmente, de duas formas básicas: a bubônica e a pneumônica. Em alguns casos, mais raros, ocorria uma terceira, a peste septicêmica (nessa, ela atinge vários órgãos promovendo uma grave hemorragia interna). Ater-nos-emos aqui mais a essas duas formas comuns. A peste bubônica era normalmente transmitida através da picada do agente portador do bacilo. Após o contato, uma vez inoculada na corrente sanguínea, o bacilo multiplica-se enchendo os gânglios e, com isso, promove um visível inchaço, formando-se bulbos externos. Esses gânglios linfáticos hemorrágicos chegavam a ficar do tamanho de uma laranja. Com a evolução da moléstia, os bulbos vão adquirindo o aspecto preto (o que lhe conferiu o nome de Peste Negra) devido à necrose acral (necropatia) nas regiões como as axilas e as virilhas. Depois de incharem em demasia, eles arrebentam. Nessa etapa de transmissão, a peste só se restringe à corrente sanguínea, aos vasos linfáticos, e é apenas transmitida pela picada da pulga contaminada. Nesse estágio, tinha letalidade (relação entre os atingidos diretamente pela picada da pulga e os que morreram) de $60 \%$ a $80 \%$, com a maioria falecendo após três ou quatro semanas. Todavia, se ela atingir os pulmões, causando hemorragias internas nesse órgão, desenvolve-se a peste pneumônica. A transmissão nesse estágio é mais simples e rápida: ela se dá por inalação de gotículas de líquidos de pessoas doentes, propagadas pelo espirro e tosse. Nessa forma, a peste é transmitida de homem para homem e, ao inalar essas gotículas, o agente biológico logo causa os sintomas de febre alta, tosse com expectoração sanguinolenta, delírios, dores musculares, inchaços e também as manchas negras na pele. Depois desses sintomas, a recuperação é quase nula e sua letalidade, no período, é de $100 \%$. Em alguns casos, a partir da manifestação dos sintomas, de 3 a 5 dias a peste ceifaria mais uma vida. Sobre a letalidade da Peste ver: FRANCO JÚNIOR, 2001: 35-36; CARPENTIER, 1962: 1071; sobre a transmissão ver: BYRNE, 2006: 20-22; SÁNCHEZ-DAVID, 2008: 133 - 135.

${ }^{3}$ Relatos de pestes ao longo da história são comuns. Algumas tornaram-se celebres e foram imortalizadas pela história como a de Atenas em 428, narrada por Tucídides em seu livro Guerra do Peloponeso; a Peste Antoniana, século II d.C., que devastou a cidade de Roma; outra no tempo do Imperador Justiniano (527-565), que se espalhou pela atual Ásia e Europa devastando, sobretudo, Constantinopla; entre outras tantas narradas em tempos romanos e Idade Média. CARPENTIER, 1962:1081. Ver também: REZENDE, 2009: 73-78..
}

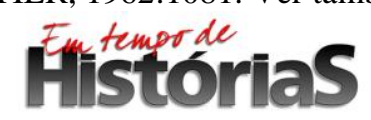


são descritas, com destaque para as manchas pretas na pele, a inevitável morte, além da correlação com o rato como agente disseminador. Apresentando as mesmas particularidades, tempos depois, uma narrativa bíblica relata um flagelo com causa semelhante sofrido pelos filisteus.

Segundo o relato do Primeiro Livro de Samuel, os filisteus usurparam a arca de Javé, de propriedade dos hebreus, e a colocaram em seu templo. Por essa atitude, foram severamente penalizados por Javé. Segundo o texto bíblico:

Depois disso [do roubo da arca pelos filisteus], a mão de Javé caiu pesadamente contra os habitantes de Azoto (...) houve um grande pânico, porque Javé feriu com tumores [sem distinção] toda a população, tanto as crianças como os adultos (...) o povo [filisteu] estava tomado de pavor mortal, porque a mão de Deus era muito pesada; os que não morriam, ficavam cheios de tumores (I Sm. 5. 6-12).

Em seguida ao castigo, tentando amenizar o sofrimento, os filisteus consultaram seus sacerdotes e resolveram devolver a arca do Deus de Israel aos hebreus. Os sacerdotes aconselharam, ademais, que empreendessem uma indenização, conforme a narrativa, de cinco tumores de ouro e cinco ratos de ouro: "façam imagens de seus tumores e dos ratos que devastam o território, e as ofereçam como homenagem ao Deus de Israel. Talvez o peso de sua mão se afaste de vocês, do seu país e do seu deus" (I Sm. 6. 1-5). Todavia, depois da arca retornar para as mãos dos hebreus, estes, similarmente, foram acometidos pela indômita peste (I Sm. 6. 17-21).

Cabe ressaltar, como fica evidente nos trechos supracitados, o fato do elo entre o rato e a peste ficar perceptível na narrativa bíblica e a construção de um conjunto de imagens que adentraria o imaginário ${ }^{4}$ da sociedade Ocidental. Caso não fosse notória tal relação, os sacerdotes não designariam como oferendas dedicadas a Javé ratos e tumores de ouro. Ainda, mais ligado ao imaginário, outra característica singular que devemos ressaltar é o interesse de conter nos livros sagrados narrativas de pestes, assim como suas particularidades e consequências imputadas pelo poder divino, servindo, igualmente, de exemplo para os demais

\footnotetext{
${ }^{4}$ Sobre o conceito de imaginário, utilizaremos as bases traçadas por Franco Júnior, para quem: imaginário é um sistema de imagens que exerce função catártica e construtora de identidade coletiva ao aflorar e historicizar sentimentos profundos do substrato psicológico de longuíssima duração. Ou, ainda mais sinteticamente, imaginário é um tradutor histórico e segmentado do intemporal e do universal. Neste caminho, entendemos, então, que o conceito refere-se à existência de um conjunto de imagens operantes na estruturação de uma época e sociedade. FRANCO JÚNIOR, 2010: 70.
} 
que pensassem em ir contra o poder de Deus e para incutir a prerrogativa dEle como o Juiz Supremo no imaginário da população cristã.

Afora a descrição bíblica, com o tempo, a Igreja procurou entender a doença pestilenta; no entanto, o fazia cristianizando previamente o possível saber médico e sujeitando-a à vontade de Deus. Por exemplo, tempos antes da grade epidemia do século XIV, ao observar alguns casos sazonais de peste, bispos - posteriormente santos para a Igreja - já relacionavam a transmissão da doença através do ar. No século VII, Isidoro (ca. 570-636), bispo de Sevilha, ao tratar da peste, defendia em seus escritos que: "mesmo sendo esta enfermidade, muitas vezes, ocasionada pelas propriedades do ar, nunca acontece, contudo, sem o arbítrio do Deus onipotente" (ISIDORO DE SEVILLA, 1982: 489). Seguindo na mesma linha, no século seguinte, Beda, em seu $97^{\circ}$ texto da Homiliae, ressalta a mesma peculiaridade. Para o monge, entre os motivos causadores da peste, estava o envenenamento do ar (característica concernente a Isidoro e uma das causas naturais estabelecida posteriormente pela medicina moderna no século XX), decorrente, contudo, da ação de uma força maléfica: o veneno desprendido dos cadáveres de cobras e escorpiões que invadiram as cidades. Segundo o Livro dos Eclesiásticos 39,30, as serpentes e os escorpiões constam na lista de "coisas" criadas e usadas por Deus para o castigo dos homens pecaminosos que transgrediram a ordem (Cf. BASTOS, 1997: 5).

Independentemente das descrições eclesiásticas e suas justificativas que cristianizavam o agente ocasionador da epidemia do século XIV, o grau de contágio era tamanho que assustava a todos. Mesmo a Igreja ficou inerte diante da situação. A Peste devastou praticamente todo o Ocidente Medieval no século XIV e deixou marcas profundas na sociedade. Não apenas por reduzir drasticamente o contingente populacional, mas por mudar e moldar, consideravelmente, o mundo medieval ao interferir nas práticas cotidianas da população, impondo-lhes novas questões religiosas e sociais para um futuro incerto e, amiúde, avesso ao proposto pela Igreja.

Peste do século XIV

Para a historiografia atual, a origem da epidemia do século XIV é praticamente um consenso, basta um exame rápido das análises do momento para se constatar as inúmeras 
consonâncias acerca de sua procedência ${ }^{5}$. Via de regra, os estudos apontam o Oriente e a Ásia central como o berço da doença, onde ela, presumivelmente, encontrava-se em estado endêmico, delimitando-se mais ao território da atual China e parte da Índia.

Relativo ao ingresso do bacilo na Europa durante a Baixa Idade Média, a hipótese mais assentida pelos pesquisadores é de que ele teria sido levado pela expansão territorial e comercial do Oriente através dos mercadores (BYRNE, 2006: 18), peregrinos (ARRIZABALAGA, 1991: 74-75) ou por cavaleiros Mongóis - a partir da expansão do império Mongol para o Oeste - que teriam atacado Caffa, na península da Crimeia, às margens do Mar Negro (FRANCO JÚNIOR, 2001: 36). No local, lutando contra a presença ocidental, os tártaros cercavam a colônia italiana quando a peste manifestou-se em seu meio. Durante o sítio da cidade, grande parte do exército mongol foi acometido pela peste e, antes de abandonarem o cerco, evocando àquilo que Jean-Noel Biraben denominou de "inovação na guerra bacteriológica" (1975: 53), eles lançaram cadáveres infectados por cima das muralhas genovesas, espalhando o bacilo dentro da cidadela. Amedrontados com a situação de célere mortandade trazida pelos cadáveres, os colonizadores italianos abandonaram o local em 1347 (FRANCO JÚNIOR, 2001: 36).

Depois de retirarem-se, embarcações genovesas provenientes da Crimeia, com o bacilo a bordo, passaram pelo arquipélago grego e pela Sicília. Em 1348, os genoveses levaram a peste para Constantinopla, Messina, Gênova e Marselha. Por exemplo, na cidade ao sul da atual França, em um ano, a maior parte da população foi dizimada. A partir desses portos mediterrânicos, ela difundiu-se pelo restante da Europa. Grosso modo, a peste propagou-se de sul para norte, quase sempre do litoral para o interior. Ela caminhava mais rapidamente pelas principais vias de comunicação e penetrava mais facilmente em regiões de alta densidade demográfica, um produto da Idade Média Central (Cf. FRANCO JÚNIOR, 2001: 36).

Assim, a peste teria alcançado a Península Itálica precisamente por meio dessas embarcações. A epidemia se propagaria após esses navios terem aportado, especialmente, em Gênova e Pisa. Gabriele de Mussis, um notário genovês contemporâneo ao início da peste, relatou a chegada dos marinheiros que estavam em Caffa. Segundo sua narrativa:

Quando os marinheiros chegaram a esses locais [Genova e Pisa], misturando-se com os habitantes, era como se tivessem trazido maus espíritos com eles: cada cidade, cada assentamento, cada lugar foi

\footnotetext{
${ }^{5}$ Acerca do debate historiográfico sobre o consenso da origem da peste ver: BYRNE, 2006: 18; LORENZO, 1984: 89; CARPENTIER, 1962:1063-1065.
} 
envenenado pela peste contagiosa, e os seus habitantes, homens ou mulheres, morreram de repente (GABRIELE MUSIS, Manuscrito. Localizado em: DERBES, 1966: 180).

Em outra narrativa, também retratando a chegada dos marinheiros em Pisa, Ranieri Sardo, um cronista contemporâneo, em seu texto "Cronica de Pisa" destaca que:

Em 1348, no início de janeiro, chegaram a Pisa duas galés genovesas que vieram da Romênia, e como chegaram à praça do peixe, qualquer pessoa [que] falou com aqueles das ditas duas galés, imediatamente adoeceu e morreu (...) e qualquer um [que] falasse com o enfermo ou tocasse aqueles mortos, imediatamente adoecia e morria. E assim se espalhou o grande furor por toda a cidade de Pisa, enquanto cada pessoa morria (RANIERI SARDO. apud. QUÍRICO, 2012: 136).

É notório nas narrativas que logo após o advento da peste houve uma considerável mudança no cotidiano e imaginário medieval, uma vez que, com sua célere transmissão, inevitavelmente a epidemia se propagou. No imaginário popular, qualquer pessoa contaminada era uma possível ameaça à vida. O grau de contágio da enfermidade era tão intenso que os relatos de cronistas contemporâneos descrevem um ambiente excruciante e funesto. $\mathrm{O}$ frade carmelita francês Jean de Venette, por exemplo, acreditava que a transmissão se dava "pelo pensamento" (BYRNE, 2006: 139). O próprio Gabriele de Mussis afirmou que a peste poderia infectar as pessoas "apenas pelo olhar" (Manuscrito. Localizado em: DERBES, 1966: 180). Segundo um tratado disseminado na época da Peste: "o momento de maior virulência da epidemia, que acarreta a morte quase que instantânea, (...) [é quando o pestilento esta morrendo e] o olhar do enfermo atinge o homem saudável, [nesse momento] a natureza venenosa passa para o outro e mata o indivíduo saudável" (Practicus, Tractatus. apud. ARRIZABALAGA, 1991: 109) Matteo Villani, um cronista florentino, descreveu: "parece que essa pestífera infecção é transmitida pela visão e pelo toque” (BYRNE, 2006: 25). O florentino continua:

(...) uma peste entre homens de todas as condições, idade ou sexo, que começavam a cuspir sangue e morriam alguns subitamente, alguns em dois ou três dias, e outros demoravam mais a morrer. E aconteceu que quem cuidasse do doente, pegando a doença ou, infectado por aquela mesma corrupção, tornava-se rapidamente doente e morria do mesmo modo; a muitos inchava a virilha, e a muitos sob as axilas à direita e à esquerda, e a outros em outras partes do corpo, [de modo] que se podia geralmente encontrar um inchaço singular em algum lugar do corpo infectado (VILLANI. apud. QUÍRICO, 2012: 137).

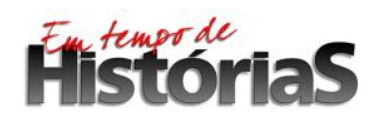


No mesmo momento e com o mesmo tom, Giovanni Boccaccio, um dos nomes mais célebres do período, ao presenciar a peste, narra a enfermidade da seguinte maneira:

no começo, apareciam, tanto nos homens como nas mulheres, seja na virilha, seja na axila, determinadas inchações. Destas, algumas cresciam como maçãs; outras, como ovos; umas cresciam mais, outras, menos; o vulgo dava-lhe a denominação de bubões. Das duas partes mencionadas do corpo, dentro em breve o citado tumor mortífero passava a repontar e a surgir por toda parte. Logo após, o aspecto da enfermidade começou a modificar-se; ela passou a pôr manchas negras ou lívidas nos doentes. Estas manchas se faziam presentes nos braços, nas coxas e em outras partes do corpo. Em algumas pessoas, as manchas se faziam grandes e raras; em outras, eram pequenas e abundantes. E, assim como, primeiro, o bubão fora, e ainda continuava a ser, indício inevitável de morte, assim também as manchas se tornaram mortíferas (BOCCACCIO, 2002: 36).

Como fica visível nos escritos dos dois cronistas florentinos, a peste era equânime e democrática, ela não distinguia vítimas, todos que com ela tivessem contato sofriam as sequelas. Segundo Hilário Franco Júnior, ao contrário do que alguns historiadores afirmam ${ }^{6}$, a má nutrição não era condição agravante para a evolução do quadro clínico (2001: 36; ver também: LORENZO, 1984: 90; CARPENTIER, 1962: 1069-1070). Ricos e pobres, organismos bem e mal alimentados, eram igualmente suscetíveis à peste. Fundamentalmente, a diferença em ser uma vítima da peste ou não, residia no fato de se estar mais ou menos exposto ao contágio. Grupos como coveiros, médicos e padres - devido à proximidade maior junto ao bacilo - eram mais atingidos por razões profissionais. A única possibilidade de salvação estava em manter-se afastado dos locais por ela tocados. Desse modo, as zonas rurais, de população mais esparsa, eram mais poupadas que as cidades (FRANCO JÚNIOR, 2001: 36).

A morte no Imaginário Medieval

Até 1348, o homem medieval foi acometido por inúmeras ondas de mortandade, contudo, foram fluxos isolados e devido a circunstâncias especiais. O fluxo de peste do século XIV, por ter sido causado por um elemento específico e ser universal em sua transmissão, é

\footnotetext{
${ }^{6}$ Em sua alegação, hoje muito contestada, JC. Russel afirma que a peste afligia, em primeiro lugar, mais homens adultos, especialmente no auge da vida (o que explicaria a elevada mortalidade nas fileiras eclesiásticas com os cleros regulares); em seguida, as crianças - independentemente do sexo. CARPENTIER, 1962: 1083.
} 
considerado por alguns como a maior catástrofe populacional da história ocidental: num intervalo de tempo menor, matou, em termos absolutos, mais do que a Primeira Grande Guerra Mundial e, em termos relativos, considerando-se a porcentagem da população europeia atingida nos dois momentos, mais do que a Segunda Guerra Mundial ${ }^{7}$. Durante o momento mais delicado da peste, entre os anos de 1348-1350, a mortandade, oscilando muito entre as regiões, foi de dois terços a um oitavo da população europeia. No geral, estima-se que a Europa ocidental perdeu cerca de $30 \%$ de seus habitantes naquela ocasião e só retomaria o nível populacional pré-peste 200 anos depois, em meados do século XVI (Cf. FRANCO JÚNIOR, 2001: 36-37).

O homem medieval, com sua existência precária, com uma estimativa de vida mais curta que a atual, com desastres, guerras e fomes - fatores que o habituava com a morte - fez da morte algo presente no cotidiano e configurou-se em um elemento corriqueiro de seu imaginário durante a Idade Média. Com efeito, o cenário com grande número de mortes ao redor, como narrado pelos cronistas contemporâneos, ocasionou mudanças na relação da população quanto à percepção da morte iminente e à brevidade da vida. Assim, sem dúvida, a mortandade e o medo de ser mais uma vítima da epidemia trouxe consigo uma transformação considerável no imaginário Medieval.

O choque suscitado pela letalidade do contágio transformou o cotidiano das pessoas. A individualidade ocasionada pelo isolamento da doença e a falta de amparo diante da situação inexplicável do momento, ocasionaram questionamentos por parte considerável da população europeia. Uma parcela dos leigos começou a inquirir sobre a capacidade de intercessão da Igreja junto ao sofrimento causado pela praga, acarretando transformações nas práticas religiosas e, consequentemente, no imaginário. Dessa forma, a esperança de serem guiados pela instituição que dizia ser representante de Deus na Terra foi diminuindo consideravelmente no decorrer do século XIV. Ao mesmo tempo, contraditoriamente, enquanto a crença na hierarquia eclesiástica e na Igreja como instituição minguava, as práticas religiosas e, consequentemente, a religiosidade com hábitos notadamente de herança cristãs na esperança de conseguir, de alguma forma, a salvação e vida eterna - notável característica cristã -, ficava cada vez maior (BOWSKY, 1964: 14-15).

\footnotetext{
${ }^{7}$ Deve-se ressaltar que outros fenômenos se juntaram a Peste e ocasionaram a queda no índice populacional. Fatores como guerras, aumento nos movimentos migratórios, menor produção de alimentos (falta de sementes, tratamento da terra e trabalho), fome, menor taxa de natalidade, elevação nos preços, entre outros, juntaram-se com a mortandade da peste e ampliaram os números da catástrofe demográfica. LORENZO, 1984: 95-96.
} 
Destarte, para os que procuravam se apoiar nas práticas religiosas para entender ou mesmo passarem ilesos pelo funesto momento, o discurso cristão serviu como base para a construção da nova realidade, gerando, por seu turno, transformações na religiosidade que provavelmente modelaram as formas de busca pela salvação eterna. Assim, o medo causado pela proximidade da morte e o anseio pela redenção tornaram-se, para muitos, quase uma obsessão (QUÍRICO, 2012: 136). Com isso, os preceitos cristãos que aludiam a qualquer particularidade da remissão das faltas e vida eterna ganharam prerrogativas importantes, sobretudo, o sacramento da extrema unção, visto como essencial para a salvação ${ }^{8}$.

Usualmente, durante a Baixa Idade Média, os sacramentos não eram vistos como imprescindíveis para uma parcela considerável dos leigos, principalmente o batismo e o casamento. De modo geral, diversos sacramentos costumavam ser menosprezados pela população na Idade Média ou, ao menos, tendiam a ser subempregados, mas não pelos clérigos (BORNSTEIN, 1993: 16). Estes continuavam lutando para implementação de uma cristianização nos rituais cotidianos. Deve-se ressaltar que a importância dos sacramentos é destacada pela Igreja ao menos desde o quarto Concílio de Latrão, em 1215 (QUÍRICO, 2012: 139). Ainda que perceptível o menosprezo dos leigos pelos demais sacramentos eclesiásticos, era comum, entre eles, mesmo em tempos não pestilentos, a cautela de estarem apropriadamente preparados para a morte e conseguirem a remissão de seus pecados terrenos. Afinal, com base na doutrina da "vida eterna", os sacramentos finais encontravam-se presentes no discurso cristão e permitiam à pessoa, no leito de morte, ter uma última chance e, com a ajuda da Igreja, procurar atenuar a culpa pelas faltas perpetradas durante a vida (BACCEGA, 2009: 25).

Em questões sociais, o rito derradeiro tornou-se parte importante da tradição medieval porque encorajava os demais a aceitar a perda de seus entes queridos, convidava outros para contribuir no momento de aceitação da ruptura no tecido social que a morte causava e voltar aos seus trabalhos cotidianos (HERLIHY, 1997: 60). Por conseguinte, a extrema unção fazia-

\footnotetext{
${ }^{8} \mathrm{O}$ sacramento derradeiro era considerado profundamente importante pela Igreja, diversos casos destacam esse serviço ofertado pelo clero como imprescindível. Em 1349, o bispo Ralph Shrewsbury de Bath edita um decreto no qual ressalta a substancial importância do rito e destaca que se os sacerdotes não fossem encontrados para sua realização, por estarem infectados ou por medo de contraírem a peste, não deveriam deixar o enfermo sucumbir sem a consumação de algo imprescindível para a salvação da alma, assim, deveria assumir esse cuidado, por zelo devocional ou por pagamento, qualquer leigo (ABERTH, Black Death, 2005, 271). Entretanto, já em 1351, o bispo de Roma recebe uma petição de clérigos questionando a possibilidade de tal ato ser empreendido por leigos. Nela, os clérigos paroquiais destacam que mendigos estariam fornecendo aos leigos serviços religiosos, inclusive sacramentos. Em sua resposta, Clemente VI condena tal atitude e destaca que a Igreja estaria perdendo suas prerrogativas para cafetões e vigaristas que estariam negligenciando os caminhos de Deus e deturpando um dos sacramentos mais importantes da Igreja (ZIEGLER, Black Death , 217).
} 
se ainda mais imprescindível no ritual de sepultamento, pois o homem não poderia morrer em pecado sem purgar suas culpas. Ao indivíduo que não possuísse o batismo ou qualquer outro sacramento, com a extrema unção, tornava-se factível a chance de ingressar no Paraíso e, consequentemente, sua alma não seria sentenciada por suas faltas pela eternidade - conforme recebesse a remissão dos erros graves e dos pecados considerados mortais pela Igreja. Essa característica atribuía, assim, ao sacramento da extrema unção um pressuposto preponderante diante dos demais sacramentos. Se ele não garantia, no mínimo proporcionava conforto e esperança de salvação na vida post mortem.

Para o homem medieval, a transição entre o mundo dos vivos e o mundo dos mortos era um processo assustador e esperava-se da Igreja o alívio dos medos associados a esse momento. Desse modo, recorria-se ao clero local para a realização do cerimonial preparatório para a morte. Nele, o religioso tradicionalmente visitava o moribundo, ouvia seus arrependimentos e sua derradeira confissão, dava-lhe o viaticum (a última comunhão) e ministrava-lhe a extrema unção (QUÍRICO, 2012: 139). Depois da morte, em circunstâncias normais, os corpos eram velados em suas respectivas casas e levados para o local de sepultamento onde seus amigos e familiares se reuniam. Por fim, o padre abençoava o corpo antes que fosse colocado sob a terra, de maneira que, após esse ritual, a alma poderia estar resguardada (HERLIHY, 1997: 60).

Todavia, a procura cada vez maior pela extrema unção gerou um impasse sério para a Igreja e, propriamente, para as práticas cristãs durante o século XIV. Dado o fato dos membros do clero serem fundamentalmente requisitados pelos pestilentos no leito de morte, o número de sacerdotes vitimados pela epidemia foi grande e, limitada fisicamente em seu contingente eclesiástico - além do medo da morte -, a Igreja foi incapaz de cumprir totalmente suas obrigações (HORROX, 1994: 235). Por exemplo: em toda Inglaterra, morreram aproximadamente 45 por cento dos sacerdotes. Na cidade de Exeter, na província de Winchester, esse número chegou aos 50 por cento dos sacerdotes (ABERTH, 2005: 95). Nos Annales Camaldulenses, do cenóbio beneditino de Santa Maria degli Angeli, em Florença, consta que, por consequência da epidemia de 1348, faleceram três quartos dos monges - muitos dos quais por presidir o sacramento da unção no leito de morte (QUíRICO, 2012: 138).

Observando-se a problemática do sacramento da extrema unção, ela torna-se um ponto imprescindível na procura de entendermos o período pestilento da Baixa Idade Média. Isso se dá devido a duas características: a necessidade do sacramento, que nos expõe a uma 
religiosidade muito arraigada na população do século XIV, em que suas práticas eram constantes e recorrentemente revisitadas pelos leigos; a proporção do temor de uma grande parcela da população com o ritual derradeiro. Em outras palavras, a extrema unção pode ser entendida como o momento que levaria o indivíduo à condenação eterna ou à purgação, mesmo que não instantaneamente, de seus pecados mundanos. Assim, o perdão no leito de morte era uma preocupação presente e, ainda, constante entre os leigos. Isso indica que havia um imaginário cristão profundamente arraigado entre a população e, mesmo com os questionamentos sobre a ineficácia da Igreja em suprir as necessidades causadas pela peste e de seu real poder como onipotente diante dos problemas mundanos, desfrutava de uma inegável força na Baixa Idade Média.

A mudança na problemática, mesmo que forçada, das práticas religiosas, fica evidente em alguns trechos dos textos de Giovanni Boccaccio. O autor do Decamerão elucida claramente esse processo. Segundo o florentino: "conforme começou a aumentar a ferocidade da peste. Esses costumes [do ritual de sepultamento] cessaram ou completamente ou em parte, e novos advieram, em seu lugar (2002: 38)”. Em outra passagem, Boccaccio acresce:

Uma só conduta, sempre igual, era posta em prática pela maior parte dos vizinhos. Estes agiam movidos não menos pelo terror de que a corrupção dos corpos lhes fizesse mal, do que pela caridade que nutriam em relação aos trespassados. Sozinhos, ou com o auxílio de alguns portadores, quando conseguiam encontra-los, tiravam das casas os cadáveres; punham os corpos diante da porta da residência, onde, principalmente de manhã, eram vistos, em quantidade incitável, pelos que andavam perambulando pela cidade, e que, ao vê-los, tomavam, providências quanto ao preparo e à remessa dos caixões (...) eram tantos mortos, que, por escassez de caixões, os cadáveres se punham sobre simples tábuas. Não foi só o caixão que recebeu dois ou três mortos ao mesmo tempo (...) em vezes infinitas se verificou que, indo dois padres, com uma cruz, para alguém, se puseram três ou quatro caixões, carregados pelos respectivos portadores, atrás do primeiro; desta maneira, onde os padres julgavam ter um morto para sepultar, tinham sete ou oito; às vezes mais. Estes mortos não mais eram homenageados, com lagrimas, ou com alguma vela ou pranteadores (...) a coisa tinha chegado a tal ponto, que já não se tratava, dos homens que morriam, com mais carinho do que agora se trata de cabras (BOCCACCIO, 2002: 40).

Em outro trecho, prossegue Boccaccio:

Para se sepultar a enorme quantidade de corpos que se levava, a toda igreja, todos os dias, quase toda hora, não bastava a terra já sagrada; e menos bastaria se se quisesse dar, a cada corpo, lugar próprio, de acordo com o costume antigo. Então, passou-se a construir igrejas nos cemitérios, porque todos os sítios estavam cheios, embora alguns

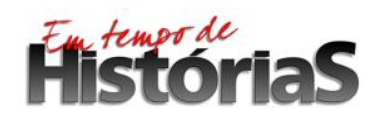

(PPGHIS/UnB) No. 29, Brasília, Ago-Dez 2016 ISSN 2316-1191 
fossem bem grandes; nessas igrejas se punham, às centenas, os cadáveres supervenientes; e estes eram empilhados como se empilham mercadorias nos navios (BOCCACCIO, 2002: 41).

Os excertos da obra de Boccaccio, assim como outras do período, demonstram que, de certa forma, a individualidade da cerimônia derradeira havia praticamente se findado com a epidemia. Agora os enterros começaram a ser em massa. O temor, sobretudo pelo receio do contágio, ocasionou, portanto, o abandono das práticas habituais das cerimônias fúnebres. Ainda, como relata um cronista de Avignon, em 1348, as famílias não apenas abandonaram as cerimônias, mas, praticamente, abandonaram seus entes enfermos:

Moribundos eram cuidados iguais a cães. Jogavam-lhes a comida e bebida no leito e depois abandonavam a casa com o ente. Finalmente, quando morriam, camponeses fortes vinham das montanhas da Provença, miseráveis e pobres e sujos, chamados gavots [coveiros]. Pelo menos, em troca de um bom pagamento, carregavam o corpo para o sepultamento. Nenhum parente ou amigo mostrava preocupação com relação ao que pudesse estar acontecendo. Nenhum padre vinha ouvir a confissão do moribundo ou administrar-lhe os sacramentos, as pessoas cuidaram apenas de sua própria saúde. (apud. HERLIHY, 1997: 62).

Como é perceptível, houve, sem dúvida, diversas reações nos vários setores da sociedade. Diametralmente, ao mesmo tempo em que uma parte da ordem religiosa furtou-se de suas obrigações ao procurar afastar-se da epidemia, seguramente, muitos se mantiveram sólidos em seus compromissos e funções eclesiásticas. Todavia, o afastamento de alguns clérigos ocasionou um aparente desarranjo nas ordens religiosas. Esse desmantelamento provocou a negligência da religiosidade mais ativa e concernente ao discurso cristão de uma parcela dos leigos, pois a comunidade se sentia abandonada por aqueles cuja obrigação era protege-los.

Com efeito, assim como ocorreu com o clero - com posições opostas diante da realidade pestilenta -, também sucedeu com os leigos. Enquanto alguns se sentiam abandonados e questionavam a Igreja como instituição, em outros a peste intensificou sua devoção. De um lado, para uma parcela da população, o abandono das práticas religiosas deuse pelo sentimento de desamparo, pois se Deus não mostrou misericórdia nem mesmo com seus sacerdotes, então, certamente, eles estavam condenados de qualquer forma. Em alguns casos, o questionamento voltava-se para um desvio da verdadeira função da Igreja, tendo ela perpetrado algumas faltas graves. Em contrapartida, para outra fração da população, a 
realidade pestilenta causou uma efervescência e uma participação maior nos ritos religiosos. Para estes, a epidemia ocasionou uma percepção das faltas cometidas e o consequente desejo de remissão dos pecados. Os fiéis intensificaram a devoção mediante o aumento da participação nos ritos e das peregrinações religiosas em santuários (ZENTNER, 2015: 20); de procissões com a eucaristia, imagens de santos protetores ou relíquias (BYRNE, 2006: 110); e das doações para mosteiros, igrejas ou hospitais administrados pelo clero (BYRNE, 2006: 137).

Essas atitudes, consequentemente, como afirma Tamara Quírico, proporcionaram a diversos mosteiros e paróquias o aumento das suas riquezas terrenas - não apenas em dinheiro, como também em terras - após o surto de 1348 (2012: 143). Desse modo, fica evidente que, durante a peste, a apreensão com seu caminho após a morte e a devoção aos preceitos cristãos tornaram-se sentimentos latentes no imaginário da população. Isso significa que a religiosidade imposta pelo momento intensificou a preocupação com a vida eterna e, assim, os fiéis procuraram amenizar qualquer falta cometida em vida, deixando seus pertences como ofertas para a Igreja.

Essa característica de fortalecimento das práticas religiosas por parcela considerável da comunidade contradiz o argumento de Zentner. Em seu texto, o historiador destaca ligeiramente a ampliação da riqueza da Igreja através dos ritos e práticas supracitadas, não obstante, reitera que a praga sacudiu profundamente somente a fé dos leigos na Igreja como instituição e não a sua fé em Deus. Ele afirma que a reputação da Igreja apenas piorou e fracassou ao adaptar-se ao novo ambiente criado pela Peste Negra (2015: 64). Para o autor, a Igreja havia, gradualmente, se tornado uma instituição secular qualquer, com uma reputação menor, submetida ao poder político e questionada em todos os níveis, determinando um declínio na fé (Cf. ZENTNER, 2015: 1-4). Segundo o autor, “a Peste Negra mudou drasticamente a imagem da Igreja nas mentes dos cristãos europeus e garantiu o declínio da sua reputação nos séculos vindouros" (2015: 22). Ao fazer tal afirmação, ele desconsidera a abrangência que as práticas cristãs alcançaram dentro do imaginário medieval, embora os questionamentos e rompimentos fossem constantes e visíveis - como o caso dos flagelantes, o afloramento de novas heresias, a debandada de membros do clero, entre outros -, a doutrina cristã e a Igreja, como instituição, ainda continuava servindo como base para manutenção de uma estabilidade social no período. Seus preceitos eram seguidos e, ainda, orientavam o cotidiano da população. 
Uma doutrina abalizada pelo medo

Um dos aspectos essenciais para o melhor entendimento do comportamento e do imaginário da população diante da epidemia configura-se, efetivamente, não somente na morte decorrente da peste, mas, principalmente, ao nosso entender, no medo do futuro post mortem - proporcionado pela sensação de angústia de não ter seus pecados purgados durante a vida e poder ser condenado ao sofrimento eterno. Isso significa que mais que o receio da morte, o sentimento de medo pela culpa, delimitado pelas diretrizes eclesiásticas, estava presente no inconsciente das pessoas por meio do imaginário.

Por conseguinte, a concepção de medo - praticamente uma paranoia alimentada pela abrangência de uma epidemia - foi motivada pelo sentimento de culpa de seus pecados, suas transgressões e desvios morais durante a vida. Ao reconhecer a responsabilidade diante da realidade pestilenta, os fiéis entendiam, também, que a epidemia não era nada mais do que a punição divina sobre as transgressões em vida. Ou seja, uma fração da população concebia a peste como um castigo infligido por Deus e, pelo sofrimento por ela causado, a esses seria anteposta a aflição eterna já em terra. A título de exemplo, Matteo Villani, ele próprio vítima da epidemia, ao tratar do assunto argumentava: "se os desastres que ocorriam em seu tempo deviam ser atribuídos a fatores outros que não a responsabilidade humana, ou se deviam ser interpretados como retribuição divina aos pecados dos florentinos [como] avareza, ganância e opressão do pobre pela usura" (VILLANI. apud QUÍRICO, 2012: 145). Seu irmão, Giovanni Villani, responde, de certa forma, sua indagação. Para ele, a única causa da mortandade sem precedentes é o julgamento divino e salienta que foi provocada pelos "nossos pecados que desagradam a Deus (..) [como] a ganância sem fim e os ganhos ilegítimos" (VILLANI, Livro II, 1991).

Com efeito, como exposto, é evidente que a concepção da peste como resultado da cólera divina era perceptível na época. Ainda, o entendimento de purgação perpetrada por Deus durante a vida remonta às Escrituras. Deveras, nos textos sagrados, são numerosos os relatos referentes às advertências e punições resultantes da ira de Deus. Amiúde, as Escrituras foram postas para a sociedade medieval como referência a ser seguida e tornaram-se, segundo Mário Jorge da Motta Bastos - não apenas para o fiel que se deparou com a peste, mas a sociedade como um todo -, "uma viva realidade que o impregnava, concedendo-lhe alimento espiritual, matéria de reflexão e conselhos de ação" para seu cotidiano (1997: 7). Com tal característica, as narrativas dos livros sagrados, sobretudo os textos veterotestamentários,

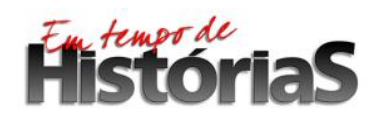


abasteceram as prelações religiosas e proveram os eclesiásticos de referências com passagens congêneres de flagelos ocasionados pela ira de Deus. Neles abundam relatos nos quais mazelas são utilizadas como exemplos, mecanismos ou mesmo armas perversas de castigo divino.

Certamente, uma das passagens mais disseminadas sobre a ira divina - não apenas no momento pestilento como em todo período medieval - foi a libertação dos filhos de Israel no Egito. Na narrativa bíblica, Javé penitenciou o faraó e os egípcios a sentirem sua pesada mão por não obedeceram suas ordens (Ex. 7, 1-6). Em Deuteronômio, ao descrever a justiça divina, o livro sagrado ressalta as mesmas características de um Deus punitivo. Nele, os hebreus abandonam Javé e são condenados: "porque são uma geração pervertida, são filhos que não têm fidelidade. (...) [eu, Javé] vou acumular males sobre eles e contra eles vou esgotar minhas flechas. Ficarão enfraquecidos pela fome, consumidos por febres e pestes violentas." (Deut. 32, 21-24).

Em outra exortação semelhante, no Levítico, após dar prerrogativas para o povo de Israel seguir e alcançar a bênção divina, os textos sagrados estabelecem, caso não obedecessem à aliança com Javé, as sanções a serem empregadas, tais como o terror da doença, como: "a fraqueza e a febre que embaçam os olhos e consomem a vida"; a fome: “vocês plantarão as sementes em vão, pois o inimigo de vocês é que as comerá (...) a terra não dará colheita e as árvores do campo não produzirão frutos"; guerra: "vocês serão derrotados pelos inimigos. Seus adversários os dominarão"; e a peste: "mandarei contra vocês a espada vingadora da minha aliança. E quando vocês se refugiarem em suas cidades, eu mandarei a peste" (Lev.26, 14-25). Esses são apenas alguns excertos que retratam a questão e, se formos a fundo, encontraremos diversos exemplos ${ }^{9}$. Via de regra, todos fundamentam e legitimam a crença que as sanções empregadas por Deus são ocasionadas devido às faltas cometidas pelos fiéis. Com efeito, nesses exemplos, assim como tantos outros, o motivo da cólera divina era a desobediência humana através de sua conduta ímpia. Igualmente, com base nas Escrituras, a epidemia tornou-se a prenunciação do advento do Anticristo e instauração de seu reinado segundo alguns textos sagrados do cristianismo, o Anticristo (I Jo. 2-18; Dn. 9-27) seria um indicativo que antecederia a Parúsia (At. 1, 11; Mt 24,27; Mt 24, 42-44; Lc. 24, 11; Lc 25-27; entre outros).

Os exemplos de pestes, fomes e guerras bíblicas eram reavivados periodicamente como justificativas que permeavam uma interpretação religiosa para o cotidiano medieval,

\footnotetext{
${ }^{9}$ Entre outros tantos exemplo: Ex. 3, 19; 9, 1-7 e 14-16; I Sam. 5, 6-12; II Sam. 24, 15-17, 25
} 
isso significa uma recorrente cristianização da realidade. Deve-se ressaltar, ainda, que ao acreditar que a epidemia era uma anunciação da ira divina, devido a alguma falta por grave ofensa ou desobediência, essa afirmação conota, novamente - assim como os rituais preparatórios para a morte -, uma característica particular. Ela demonstra e reforça que a visão de uma ortodoxia, embora sempre questionada e adaptada, foi aplicada e que esse ponto de vista foi tomado como referência em um contexto no qual a religiosidade concernente ao discurso cristão estava impregnada no imaginário da população.

Embora esse panorama da ira divina já estivesse no imaginário da população, o contexto pestilento do século XIV reviveu-o e reafirmou-o. Como consequência da interpretação do cenário de caos e aflição ocasionado pelo surto da peste sendo fruto da cólera Divina, muitos a viram como prenúncio de uma factível sanção máxima de Deus e o imediato fim dos tempos. No período, um crescente temor do Juízo Final era perceptível e os presságios milenaristas afloraram novamente - como ocorreu em inúmeros momentos da Idade Média, em que várias ocasiões eram expostas ou entendidas como pertencentes ao decurso do Juízo Final. Anunciações de um possível fim dos tempos, corriqueiramente, perpassaram o imaginário da população desde os primeiros anos do Cristianismo; perseguições sofridas pelos primeiros cristãos, infligida pelos Imperadores romanos; grupos heréticos como os milenaristas que pregavam a proximidade do Juízo Final; invasões germânicas; o próprio desmantelamento do Império Romano, entre outros tantos, são possíveis exemplos dessa percepção milenarista.

Desse modo, é notório que o contexto de devastação decorrente de uma epidemia insólita e pouco compreendida configurou-se por um amálgama de sentimentos dos mais diversos que abrangem: a impotência ante uma realidade desconhecida que deixava apenas rastro de morte e destruição; instabilidade social com o medo de qualquer um que se aproximasse; ou mesmo a ineficiência civil causada a partir das instituições que cada dia menos eram capazes de prover as necessidades materiais e espirituais das pessoas, ocasionando uma desordem administrativa, visto que muitos morreram ou abandonaram seus postos para se refugiarem em locais afastados.

Percebe-se com o exposto que se tomarmos a peste como uma sanção divina de caráter repressivo, ela não passaria de um elemento presente dentro de um conjunto de fatores mais abrangente do Imaginário Medieval, visto que a principal característica da punição infere o papel de Deus como um juiz supremo e justo, presumindo, consequentemente, o estabelecimento e a disseminação de suas leis entre a população - o que demonstra, de certa 
maneira, a abrangência que as práticas e o imaginário religioso alcançavam no período. Outro elemento do conjunto de fatores é a repreensão que, a princípio, imputa um delito cometido. Desse modo, o Juiz Supremo não seria injusto ao penalizar um inocente, o indivíduo ou a comunidade que sofresse por alguma sanção. Estes já estariam qualificados com a culpa. Diante disso, o castigo infligido através da desolação da peste indica que o arbítrio de punir estava a cargo apenas de Deus e, ainda, serve como um alerta para os fiéis ao indicar que a vida com seus caminhos estranhos, tortuosos, às vezes difíceis, é o melhor trajeto para conseguir alcançar a redenção e um lugar junto ao altíssimo no paraíso.

Essa afirmativa sugere-nos uma questão. Existiria, no período, alguma outra infração atribuída aos homens ${ }^{10}$ - entendida por eles como grave - que não fosse a atribuição de culpa pelo pecado de desobediência que causaria uma epidemia como a da peste? Se no imaginário popular do período foi possível uma indagação diferente, sua resposta pode ser inacessível. A nosso ver, embora difícil de responder, essa indagação parece plausível visto que é uma questão, de certo modo, diferente da inquerida e respondida pela própria Igreja. Geralmente, os textos não narram outras questões que não tivessem culpado o homem por suas faltas. Assim, podemos afirmar que a narrativa cristã alimentou-se dessa questão que proporciona uma ambiguidade ao possibilitar, simultaneamente, o sentimento de angustia do desconhecido e o reconhecimento do inquestionável discernimento do divino com sua compreensão e remissão das faltas. Destarte, a peste configurou-se, para o discurso cristão, como um exemplo no qual a resposta de Deus às transgressões e desobediências humanas são faltas que maculam a população, característica que, como vimos, tem seu respaldo nos textos veterotestamentários. Inevitavelmente, tanto no século XIV como nos escritos sagrados do cristianismo os pecados requerem a purgação pela pesada mão de Deus.

Dessa maneira, como afirma Bastos, “se o bubão pestífero é o sinal do mal, que conspurca a pele, dilacera, externaliza-se a doença/pecado introjeta, em primeiro lugar, sentimentos e condutas determinadas: o medo, a angústia, a culpa e o remorso" (1997: 12). Para a Igreja, a epidemia pestilenta configura-se como um agente fundamental para a culpabilização dos leigos e futura redenção de suas faltas diante do Deus misericordioso.

\footnotetext{
${ }^{10}$ Existiam diversos fatores que os leigos acreditavam ser os motivos causadores da peste, porém, todos transcendiam os limites humanos. Jon Arrizabalaga divide seu texto em diversas causas que poderiam ser o fundamento da peste, tais como: as causas naturais, celestes, artificiais ou sobrenaturais (1991: 87-109). Elas poderiam causar a peste isoladas ou em conjunto com outros fatores, contudo, nenhuma de responsabilidade humana que não fosse o pecado da desobediência.
} 
Conclusão

Com o exposto, fica evidente que o fluxo da Peste Negra realmente ocasionou transformações perenes no imaginário e na religiosidade da população no século XIV, propiciadas, sobretudo, pelo medo da morte e de uma provável era apocalíptica proveniente da culpa humana. Faz-se necessário ressaltar que costumasses ondas pestilentas ocorreram por toda Europa Medieval durante o século XIV. Episódios com epidemias de menor rigidez e, consequentemente, uma menor mortandade foram constantemente narrados após o funesto fluxo de 1348 e o temor das sequelas era enorme. Seguramente, a reincidência da peste carrega consigo a memória do pânico e das consequências ocasionadas pelas epidemias precedentes, especialmente do surto de 1348.

$\mathrm{O}$ medo, o horror, o desespero e a inquietude diante do desconhecido afloravam novamente o sentimento de desamparo em um momento obscuro. Por conseguinte, ao mesmo tempo em que atenuava alguns comportamentos, revigorava as práticas religiosas da congregação. Ou seja, novas pestes sempre serviram para rememorar a culpa humana do pecado e a piedade divina diante das faltas cometidas. Portanto, em qualquer período, um surto pestilento seria, por excelência, o momento de remissão - segundo a prática cristã - dos pecados mundanos para adquirir a salvação da alma a partir da consolidação e interiorização da culpa. Assim, os que forem purgados e julgados como dignos, contemplariam a face da Justiça no Paraíso (Sm. 17-15; Mt. 25 31-46) e nunca mais padeceriam de mal algum. Desse modo, a punição advinda da peste - para a Igreja -, em última análise, pretende comprovar aos cristãos o quão efêmera é sua presença na Terra e a magnitude das ações misericordiosas de Deus na remissão das faltas humanas.

\section{Referências bibliográficas}

ABERTH, John (ed.). The Black Death: The Great Mortality of 1348-1350: A Brief History with Documents. New York: Bedford/St. Martin's, 2005.

ARRIZABALAGA, JON. La Peste Negra de 1348: los orígenes de la construcción como enfermeda.d de uma calamidad social In: Acta Hispanica ad Medicinae Scientiammque Historiam Illustrandam. Vol. 11, 1991, pp. 73-117 Barcelona.

BACCEGA, Marcus. Idade Média, Tempo do Sacramento. Revista Ágora, Vitória, n.10, 2009, pp.1.-28.

BASTOS, Mario J. M. Pecado, Castigo e Redenção: a Peste como Elemento do Proselitismo Cristão (Portugal, Séculos XIV/XVI). In: Tempo. Rio de Janeiro: Editora Tempo, Vol. 2, 1997. pp. 1-17. 
BIRABEN, Jean-Noël. Les hommes et la peste en France et dans les pays méditerranéens. tome I, Paris La Haye Mouton. 1975.

BOCCACCIO, Giovanni. O decamerão. Trad. Raul de Polillo. Belo Horizonte: Itatiaia, 2002.

Bíblia Sagrada. Edição pastoral. São Paulo: Sociedade Bíblica Católica Internacional e Paulus, 1990.

BOWSKY, W.M. The impact of the Black Death upon Sienese government and society. In: Speculum, vol. 39, $\mathrm{n}^{\mathrm{o}} 01,1964$.

BYRNE, Joseph Patrick. Daily life during the Black Death. London: Greenwood Press. 2006.

CARPENTIER, Elisabeth. Autour de la peste noire: famines et épidémies dans l'histoire du XIVe siècle. In: Annales. Économies, Sociétés, Civilisations. 17e année, N. 6, 1962. pp. 1062-1092.

CASTIGLIONI, Arturo. História da Medicina. $2^{\circ}$ vol. Companhia Nacional: São Paulo, 1947.

FRANCO JÚNIOR, H. A Idade Média: Nascimento do Ocidente. São Paulo: Brasiliense, 2001.

FRANCO JÚNIOR, H. O fogo de Prometeu e o escudo de Perseu: reflexões sobre mentalidade e imaginário. In: Os três dedos de Adão: Ensaios de mitologia Medieval. São Paulo: Edusp, 2010.

GABRIELE MUSIS, Manuscrito. Localizado Im: DERBES VJ. de Mussis and the great plague of 1348. JAMA: The Journal of the American Medical Association. 1966; p. 179-82.

HERLIHY, David. The Black Death and the Transformation of the West. Cambridge: Harvard University Press, 1997.

HORROZ, Rosemary. The Black Death Manchester: Manchester Medieval Soueces, 1994.

ISIDORO DE SEVILLA. Etimologias, I, Madrid: BAC, 1982.

LORENZO, Ángel Vaca. LA PESTE NEGRA EN CASTILLA: Aportación al estudio de algunas de sus consecuencias económicas y sociales. In: Studia Historica: Historia Medieval. Studia Historica: Historia Medieval. Vol.2. Salamanca: 1984. pp. 89- 107.

QUÍRICO , Tamara. Peste Negra e escatologia: os efeitos da expectativa da morte sobre a religiosidade do século XIV. In: Revista Mirabilia, Volume $14 \mathrm{n}^{\circ}$ 1. 2012. pp. 135-255.

RANIERI SARDO. Cronica di Pisa (org. Ottavio Banti). Fonti per la storia d'Italia, n. ${ }^{o}$ 99. Roma: Istituto Storico Italiano per il Medioevo, 1963.

REZENDE, JM. À sombra do plátano: crônicas de história da medicina. As grandes epidemias da história. São Paulo: Editora Unifesp, 2009.

SÁNCHEZ-DAVID, Carlos E. LA MUERTE NEGRA. "EL AVANCE DE LA PESTE”. In: Revista Med, Volume 16. No 1. Bogotá, 2008. p. 133 - 135.

VILLANI, Giovanni. Nova Crônica de Giovanni Villani. Giovanni Porta (ed.), 3 vols., Fundação Pietro Bembo, Ugo Guanda. Parma, 1991.

ZENTNER, McLaurine H. The Black Death and its Impact on the Church and Popular Religion. Oxford: Oxford Press, 2015. 